DOI https://doi.org/10.30525/978-9934-588-37-2.1.16

\title{
ДЕЯКІ МЕТОДИЧНІ АСПЕКТИ ФОРМУВАННЯ УМІНЬ АНГЛІЙСЬКОГО АРГУМЕНТАТИВНОГО ПИСЬМА МАЙБУТНІХ ПРАВОЗНАВЦІВ ЗА УМОВ Е-НАВЧАННЯ
}

Заярна I. C.

\section{ВСТУП}

У сучасному глобалізованому світі вміння аргументовано викладати свої думки на письмі англійською мовою $є$ визначальним для юриста, адже доводити власну позицію чи спростовувати аргументи опонентів- це основоположне вміння правника. Спеціальні дослідження 3 методики, лінгвістики, психології, психолінгвістики, логіки, теорії права, присвячені цій проблематиці, вивчають широкий ряд питань, безпосередньо пов'язаних із е- навчанням англійського аргументативного письма (далі ААП) студентів-юристів. Вагомими для нас $\epsilon$, зокрема, результати наукових досліджень учених-лінгвістів: А.Д. Бєлової, Ф.Х. ван Еемерена (F. Eemeren), Б.I. Маленького, І.І. Пірог; учених-правників: Р. Алекси, M.I. Козюбри, П.М. Рабіновича, С. Тульміна (S. Toulmin); учених-логіків: А.Є. Конверського, Л.Г. Комахи, А.П. Політюк, І.В. Хоменко; ученихпсихолінгвістів: І.А. Зимньої, А.А. Леонтьєва, О.М. Лозової, А.Р. Лурії; учених-психологів: Е.Р. Дамірчарі, Л.А. Києнко-Романюк, П.Г. Лубочнікова, Н.Ю. Туласинової та ін.

Особливий науковий інтерес становлять результати спеціальних досліджень учених-методистів І.Б. Антонової (методична ефективність використання письма як засобу навчання аргументації у немовному виші) ${ }^{1}$, О.А. Баранової (методика навчання аргументованого писемного висловлювання) $)^{2}$, Ю.В. Батуріної (формування аргументативних стратегій у магістрів-психологів із використанням мережевих комп'ютерних технологій) $)^{3}$, С.В. Білоус (навчання майбутніх філологів

1 Антонова И.Б. Методическая эффективность использования письма как средства обучения аргументированию в неязыковом вузе: английский язык : дис. ... канд. пед. наук : 13.00.02 / Моск. лингвистический ун-т. Москва, 1994. 254 с.

Баранова Е.А. Методика обучения аргументированному письменному высказыванию: на материале французского языка, языковой факультет : автореф. дис. ... канд. пед. наук : 13.00 .02 / Моск. гос. гуманитар. ун-т им. М.А. Шолохова. Орел, 2013. 23 с.

3 Батурина Ю.В. Формирование аргументативных стратегий у магистрантовпсихологов с использованием сетевых компьютерных технологий: на материале английского языка : дис. ... канд. пед. наук : 13.00 .02 / Санкт-Петербургский гос. ун-т. Санкт-Петербург, 2015. 275 с. 
англійського усного монологічного персуазивного мовлення $)^{4}$, Г.М. Гаврилової (формування писемномовленнєвої аргументативної компетенції у студентів гуманітарних спеціальностей) ${ }^{5}$, В.В. Дацюк (навчання студентів східних факультетів аргументативних стратегій англомовного ділового дискурсу) 6 , С.М. Мусульбес (навчання аргументативного дискурсу у сфері писемного спілкування) ${ }^{7}$, Т.О. Румянцевої (навчання аргументативного спілкування студентів 3 курсу мовних педагогічних вишів) ${ }^{8}$. Водночас, незважаючи на всебічний інтерес учених і суттєві здобутки в галузі методики навчання аргументативного мовлення, методика е-навчання ААП майбутніх правознавців ще не була предметом спеціального дослідження i вимагає окремого грунтовного вивчення. 3 огляду на вищезазначене вважаємо за доцільне в межах цієї роботи розробити етапи е-навчання ААП студентів-правників, а також створити дієву систему вправ i завдань для їх реалізації.

\section{1. Етапи е-навчання англійського аргументативного письма майбутніх правознавців}

Питання етапності навчання іншомовного письма й аргументативного мовлення були предметом спеціальних досліджень вітчизняних i зарубіжних вчених. Так, О.В. Патієвич, досліджуючи етапи навчання стилістично унормованого наукового писемного мовлення, виділяє такі: орієнтаційний (формування знань про стилістичні норми наукових текстів), дотекстовий (формування навичок вживання в науковому мовленні стилістично унормованих мовленнєвих одиниць), текстово-трансформаційний (формування умінь моделювати стилістично унормовані наукові тексти із готового текстового матеріалу) та текстово-проектний (формування умінь написання стилістично унормованих наукових текстів iз

${ }^{4}$ Білоус С.В. Навчання майбутніх філологів англійського усного монологічного персуазивного мовлення : дис. ... канд. пед. наук : 13.00 .02 / КНУ імені Т. Шевченка. Київ, 2017. 228 с.

5 Гаврилова А.Н. Формирование письменно речевой аргументативной компетенции у студентов гуманитарных специальностей (английский язык) : дис. ... канд. пед. наук : 13.00.02 / Санкт-Петерб. гос. ун-т. Санкт-Петербург, 2011. 277 с.

6 Дацюк В.В. Обучение студентов восточного факультета аргументативным стратегиям англоязычного делового дискурса : дисс. ... канд. пед. наук : 13.00.02 / Санкт-Петербургский гос. ун-т. Санкт-Петербург, 2016. 233 с.

${ }^{7}$ Мусульбес С.Н. Обучение аргументирующему дискурсу в сфере письменного общения: (языковой вуз, продвинутый этап, английский язык) : дис. ... канд. пед. наук : 13.00.02 / Моск. гос. лингв. ун-т. Москва, 2005. 202 с.

8 Румянцева Т.А. Обучение аргументативному общению студентов 3 курса языкового педагогического вуза: (на материале немецкого языка) : дис. ... канд. пед. наук : 13.00.02 / Пензенский гос. пед. наук им. В.Г. Белинского. Пенза, 1999. 240 с. 
використанням методу проекту) ${ }^{9}$. Незважаючи на обгрунтованість цієї моделі, вона не відображає специфіки навчання аргументативного мовлення й особливостей правової сфери спілкування, в межах якої реалізується ААП. Ми погоджуємося з логікою автора щодо змісту дотекстового та текстово-проектного етапів. Водночас під час навчання ААП вбачаємо можливим оминути текстово-трансформаційний етап, який $є$ доцільним у процесі створення наукових текстів, але не під час продукування жанрів юридичного дискурсу.

На думку О.В. Цепкало, навчання професійно-спрямованого англомовного писемного спілкування має відбуватися у три етапи: підготовчий, на якому дослідник пропонує активізувати предметні знання у середовищі іноземної мови та сформувати необхідні мовні навички; когнітивно-комунікативний етап передбачає формування стратегій обробки первинного тексту в ході його розуміння, оцінювання та присвоєння інформації; комунікативний, на якому здійснюється формування комунікативних умінь писемного мовлення ${ }^{10}$. На нашу думку, означена модель лише частково відповідає специфіці е-навчання ААП. Зокрема, ми підтримуємо позицію автора щодо включення підготовчого етапу, спрямованого на трансформацію спеціально-правових знань у площину іноземної мови. Проте ця модель не відображає особливостей аргументативного мовлення та дистанційного навчання, що є ключовими аспектами у межах предмету нашого дослідження.

Л.Є. Шевніна виокремлює етап презентації, на якому студенти знайомляться зі структурою жанрової матриці, стратегіями та тактиками побудови жанрів певної підмови; етап партикуляції передбачає формування технічних навичок оформлення ділової документації, побудови зв'язного висловлювання та відповідних лексичних і граматичних мовленнєвих навичок; етап формування ментальної схеми фрейму, націлений на вдосконалення вмінь студентів складати тексти жанрів 3 опорою на жанровий фрейм ${ }^{11}$. Навчання визначених жанрів ААП студентів-юристів реалізується в межах

9 Патієвич О.В. Методика навчання стилістичної унормованості наукового писемного англійського мовлення майбутніх фізиків в умовах магістратури : дис. ... канд. пед. наук : 13.00.02 / М-во освіти і науки України, Київ. нац. ун-т імені Тараса Шевченка. Київ, 2015. С. 101-103.

10 Цепкало О.В. Методика навчання комунікативних стратегій професійно спрямованого англомовного писемного спілкування майбутніх фахівців 3 машинобудування : дис. ... канд. пед. наук : 13.00.02 / НТУ КПІ імені I. Сікорського. Київ, 2017. С. 84-85.

11 Шевніна Л.С. Формування жанрової компетенції в англійському діловому писемному мовленні майбутніх менеджерів туризму : автореф. дис. ... канд. пед. наук : 13.00.02 / ПНПУ ім. К.Д. Ушинського. Одеса, 2012. С. 9-12. 
юридичного дискурсу та загалом відповідає моделі, запропонованій Л.Є. Шевніною. Проте означена модель не включає особливості аргументативного мовлення та специфіку правової сфери, в межах якої воно реалізується.

Реалізація комплексу вправ для навчання аргументативного мовлення англійською мовою, на думку Ю.В. Батуріної, має відбуватися у два етапи: домовленнєвий i мовленнєвий. Метою першого етапу дослідниця вбачає формування умінь аргументативного мовлення 3 використанням визначених стратегій у межах умовної (навчальної) комунікації. На цьому етапі пропонується використовувати вербальні та невербальні опори. Мовленнєвий етап націлений на удосконалення умінь i навичок аргументативного мовлення 3 використанням стратегій, якими студенти оволоділи на попередньому етапі ${ }^{12}$. Означена модель, хоч i описує ключові фази аргументативного мовлення, проте, на наше переконання, вимагає деталізації. Зокрема, на домовленнєвому етапі доцільно розмежувати аргументаційний і мовний блоки, а мовленнєвий етап поділити на дотекстовий і текстово-продукувальний.

Значний науковий інтерес у межах цього дослідження становить етапність, запропонована І.Б. Антоновою. На думку дослідниці, організація роботи над аргументаційним текстом передбачає чотири взаємопов'язані між собою етапи: орієнтовно-підготовчий, тренувальний, домовленнєвий і мовленнєвий ${ }^{13}$. Цілком погоджуємося 3 логікою побудови етапів і їх взаємозв'язком, який проявляється в наступності цілей, об'єктів, прийомів, навчальних задач та опор. Однак запропонована етапність не може бути повністю релевантною до навчання ААП, оскільки не враховує специфіку правової сфери спілкування, в межах якої реалізується ААП. Визначення тези, пошук аргументів і формулювання висновків базуються на предметних знаннях студентів у галузі права, і цей аспект має бути обов'язково врахований під час розробки підсистеми вправ і завдань для навчання ААП.

Науковий інтерес становлять здобутки Г.М. Гаврилової, котра, досліджуючи етапи формування писемномовленнєвої аргументаційної компетенції, виділяє рецептивно-аналітичний, тренувальний та аргументаційний етапи. Рецептивно-аналітичний етап, на думку вченої,

12 Батурина Ю.В. Формирование аргументативных стратегий у магистрантовпсихологов с использованием сетевых компьютерных технологий: на материале английского языка : дис. ... канд. пед. наук : 13.00 .02 / Санкт-Петербургский гос. ун-т. Санкт-Петербург, 2015. С. 144-145.

13 Антонова И.Б. Методическая эффективность использования письма как средства обучения аргументированию в неязыковом вузе: английский язык : дис. ... канд. пед. наук : 13.00.02 / Моск. лингвистический ун-т. Москва, 1994. С. 113. 
належить до дописемної та доаргументаційної фази i націлений на розпізнавання аргументативних текстів серед інших функціональностилістичних типів текстів, а також на виокремлення основних компонентів аргументативного тексту та логіко-композиційних схем. На тренувальному етапі відбувається формування стійких стереотипів структур аргументативного тексту, у процесі оволодіння якими студенти створюють власні аргументативні тексти 3 використанням різних типів опор. Аргументативний етап передбачає самостійну роботу студентів над створенням власного аргументативного тексту, чому передує пошук, вибір адекватних аргументів, мовних засобів i засобів логічної зв'язки ${ }^{14}$. Така модель становить значний інтерес у межах нашого дослідження, адже відображає поетапну логіку роботи над аргументаційним текстом. Проте навчання студентів-юристів вимагає врахування правової сфери спілкування й особливих мовних засобів, притаманних лише юридичному письмовому дискурсу, що має бути обов'язково враховане у процесі розробки системи вправ і завдань для е-навчання ААП.

Проведений аналіз наукових досліджень дає можливість стверджувати: що вчені одностайні в тому, що навчання аргументативного письма у ЗВО має реалізовуватися поетапно. Проаналізувавши низку моделей навчання іншомовного й аргументативного мовлення, ми можемо зробити висновок, що вони лише частково задовольняють організацію процесу е-навчання ААП студентів-юристів. Тому перед нами постає питання щодо визначення етапів е-навчання ААП, які враховуватимуть специфіку технічноопосередкованого навчання, особливості навчання аргументативного мовлення та професійної сфери спілкування, в межах якої воно здійснюється.

Беручи до уваги грунтовні напрацювання вчених-методистів в етапності навчання аргументативного писемного мовлення та враховуючи поставлені перед нами цілі та задачі, ми визначили такі чотири етапи е-навчання ААП у межах юридичного дискурсу: 1 етап підготовчий; 2 етап - аналітичний; 3 етап - тренувальний; 4 етап текстово-продукувальний ${ }^{15}$.

14 Гаврилова А.Н. Формирование письменно речевой аргументативной компетенции у студентов гуманитарных специальностей (английский язык) : дис. ... канд. пед. наук : 13.00.02 / Санкт-Петерб. гос. ун-т. Санкт-Петербург, 2011. C. $167-169$.

15 Заярна I.C. Етапи навчання англійського аргументативного письма майбутніх правознавців. Актуальні питання розвитку юридичної науки та практики : матеріали Міжнародної науково-практичної конференції (15 листопада 2019 р.) / за заг. ред. І.С. Гриценка, І.С. Сахарук. Київ, 2019. С. 578-580. 
Підготовчий eman спрямований на формування мовленнєвих навичок у продукуванні ААП у межах відповідного жанру. На цьому етапі ставимо за мету подолання мовних труднощів, спричинених незнанням особливостей юридичного письма, лексичних одиниць, граматичних структур і мовних кліше, притаманних аргументативному письму юриста, а також частково предметних труднощів, які пов'язуємо 3 низьким рівнем сформованості у студентів-юристів першого року навчання предметної компетентності.

Реалізація поставлених цілей відбувається шляхом виконання лексичних i граматичних вправ, що розробляються на основі предметно-значущих текстів (законодавчого акта, директиви, контракту, положення, тощо).

Сформовані під час першого етапу необхідні мовленнєві навички слугують необхідним підгрунтям для реалізації другого аналітичного - етапу, безпосередньо пов'язаного 3 роботою над текстами-зразками визначених жанрів юридичного дискурсу. Аналітичний етап націлений на визначення композиційних і жанровостилістичних особливостей різних жанрів юридичного дискурсу: листапоради, листа-попередження, листа-відповіді на попередження, юридичного меморандуму, позовної заяви тощо.

Для успішної реалізації аналітичного етапу розробляємо вправи рецептивно-аналітичного характеру на аналіз готових текстів визначених жанрів, їхньої композиції, мовних засобів для вираження тези, аргументів, висновків, а також засобів зв'язку композиційних частин.

Третій - тренувальний - етап спрямований на досягнення таких цілей: 1) формулювання правового питання (тези); 2) формулювання аргументів; 3) формулювання правового висновку; 4) подолання логічних труднощів, які зумовлені логікою побудови текстів i визначаються формально-логічною компетентністю.

Для успішної реалізації тренувального етапу розробляємо групу тренувальних завдань репродуктивно-трансформаційного характеру, котра покликана усунути логіко-композиційні труднощі аргументативного письма, допомогти студентам оволодіти змістом i формою аргументативного тексту та сприяє відпрацюванню окремих операцій і дій, які готують студентів до повноцінної мовленнєвої діяльності в межах ААП.

Сформованість мовленнєвих навичок та аргументаційних умінь, а також знань композиційних i жанрово-стилістичних особливостей визначених жанрів юридичного дискурсу передбачають їх подальше інтегрування в уміння англійського аргументативного письма, що реалізується на четвертому - текстово-продукувальному - етапі. 
Суть цього етапу полягає в написанні власних аргументаційних текстів у визначених жанрах юридичного дискурсу. Цілями текстовопродуктивного етапу визначаємо 1) удосконалення аргументаційних умінь і 2) формування текстово-продукувальних умінь. Досягнення зазначених цілей відбувається шляхом виконання завдань, спрямованих на вирішення конкретного кейсу.

Таким чином, запропонована етапність навчання ААП майбутніх правознавців покликана реалізувати поставлені навчальні цілі та завдання, враховуючи специфіку аргументативного письма й особливості професійної сфери спілкування, в межах якої воно здійснюється. Водночас успішність реалізації визначених нами етапів е-навчання ААП майбутніх юристів вимагає створення ефективної системи вправ і завдань.

\section{2. Підсистема вправ і завдань для е-навчання англійського аргументативного письма майбутніх правознавців}

Вважаємо доцільним зазначити, що у межах цього дослідження вправу, услід за Н.К. Скляренко, будемо розуміти як «спеціально організоване в навчальних умовах багаторазове виконання окремих операцій, дій або діяльності 3 метою оволодіння ними або їх удосконалення» ${ }^{16}$. Як слушно зазначає І.Л. Бім, вправа націлена на вирішення конкретного методичного завдання, будується на певному іншомовному навчальному матеріалі, і в ній безпосередньо задані ті дії оформлення й оперування, які підлягають формуванню ${ }^{17}$. У свою чергу, навчальне завдання, поділяючи позицію В.М. Плахотника, розуміємо як форму організації самостійної діяльності студента, націленої на виконання сукупності послідовних дій для досягнення визначених цілей ${ }^{18}$. Навчальне завдання має одноразовий характер (хоча повторне виконання можливе) та виконується на основі сформованих навичок i вмінь; виконання навчального завдання може тривати від кількох хвилин до кількох годин і більше, ключі неможливі, оскільки результат виконання кожного студента індивідуальний ${ }^{19}$.

Для досягнення запланованого результату - формування умінь ААП - вправи та завдання організовуємо в систему, котру, услід за

16 Методика викладання іноземних мов у середніх навчальних закладах : підручник / кол. авт. під керівн. С.Ю. Ніколаєвої. Київ : Ленвіт, 2002. С. 64.

17 Бим И.Л. Методика обучения иностранным языкам как наука и проблема школьных учебников: опыт системно-структурного описания. Москва : Русский язык, 1977. С. 191.

18 Плахотник В.М. Чи можуть вправи бути комунікативними. Іноземні мови. 2009. № 3. C. 4.

${ }^{19}$ Там само. С. 5. 
С.Ф. Шатіловим, визначаємо як «сукупність необхідних типів, видів $\mathrm{i}$ різновидів вправ та завдань, які виконуються в такій послідовності та в такій кількості, щоб враховувати закономірності формування мовленнєвих навичок та умінь у різних видах мовленнєвої діяльності, що дозволить забезпечити максимальний рівень оволодіння іноземною мовою за відповідних умов» ${ }^{20}$. Оскільки наше дослідження спрямоване на оволодіння уміннями окремого виду мовленнєвої діяльності писемного мовлення, нашу систему вправ і завдань розуміємо як підсистему вправ і завдань (тобто систему нижчого порядку, яка підпорядковується системі вправ вищого порядку), всередині якої розрізняємо групи вправ i завдань, націлених на оволодіння конкретними вміннями та навичками ААП майбутніх правників. На основі вищевикладеного сформулюємо визначення поняття «підсистема вправ $i$ завдань для е-навчання англійського аргументативного письма»: сукупність груп вправ і завдань різних видів та типів, які здатні забезпечити максимальний рівень оволодіння уміннями та навичками ААП під час е-навчання за умов їх поетапного виконання.

Під час розробки підсистеми вправ і завдань для навчання ААП спираємося, за Н.К. Скляренко, на методичні вимоги до вправ і завдань для формування іншомовних мовленнєвих навичок i вмінь: комунікативність вправи, вмотивованість мовленнєвих дій студентів, створення комунікативних ситуацій, культурологічну спрямованість, новизну, ступінь забезпечення студентів необхідними зразками й опорами $^{21}$. Розроблені вправи та завдання для навчання ААП передбачають три- або чотирифазову структуру: вправи містять такі компоненти, як завдання, зразок виконання (необов'язково), безпосередньо виконання та контроль ${ }^{22}$; у свою чергу, завдання складається 3 інструкції, передбачуваного результату (за потреби), виконання дій, контролю виконаного завдання та рефлексії ${ }^{23}$.

Не менш важливим під час розробки підсистеми вправ і завдань для е-навчання ААП студентів-юристів $є$ врахування низки умов оволодіння необхідними вміннями та навичками: 1) особливостей навчання, опосередкованого комп'ютером; 2) часових параметрів; 3) специфіки

20 Шатилов С.Ф. Методика обучения немецкому языку в средней школе. Москва : Просвещение, 1986. С. 59.

21 Скляренко Н.К. Сучасні вимоги до вправ для формування іншомовних мовленнєвих навичок та вмінь. Іноземні мови. 1999. № 3. С. 3-7.

${ }^{22}$ Там само. С. 4.

${ }^{23}$ Білоус С.В. Навчання майбутніх філологів англійського усного монологічного персуазивного мовлення : дис.... канд. пед. наук : 13.00.02 / КНУ імені Т. Шевченка. Київ, 2017. С. 101. 
правової сфери спілкування, у межах якої реалізується ААП. Так, особливості навчання, опосередкованого комп'ютером, передбачають технічно-опосередкований характер комунікації суб'єктів навчання. Це вимагає чітких інструкцій до кожної вправи та завдання, а також розширеної рефлексії за результатами їх виконання. Враховуючи особливості навчання на відстані та неможливість спостереження за процесом виконання вправ і завдань всіма студентами, вважаємо за доцільне обмежувати час, відведений на виконання кожної вправи, та кількість можливих спроб. Це сприятиме ефективному оцінюванню навчальних досягнень студентів. Крім того, вправи та завдання, які перевіряються системою, повинні мати однозначні відповіді та чітку форму. Часові параметри е-навчання ААП передбачають обмеженість часом, що відводиться на позааудиторну роботу під час вивчення дисципліни «Іноземна мова за фаховим спрямуванням», що вимагає інтенсифікації підсистеми вправ i завдань для е-навчання ААП. Специфіка правової сфери спілкування, в межах якої реалізується ААП, передбачає використання автентичного та чинного законодавчого матеріалу для створення системи вправ і завдань. Навчання ААП здійснюється в межах навчання писемного мовлення та 3 метою підготовки майбутніх юристів до професійної діяльності.

Представимо підсистему вправ і завдань для е-навчання ААП студентів-юристів, що реалізується відповідно до визначених нами етапів, і проілюструємо кожну групу вправ і завдань відповідними зразками. Для кращої зручності сприйняття підсистему вправ і завдань для е-навчання ААП студентів-юристів подаємо у формі таблиці:

Таблиця 1

\section{Підсистема вправ та завдань}

\section{для е-навчання ААП студентів-юристів}

\begin{tabular}{|l|l|l|}
\hline $\begin{array}{l}\text { Підготовчий } \\
\text { етап }\end{array}$ & $\begin{array}{l}\text { Група 1. } \\
\text { лексичні та } \\
\text { граматичні } \\
\text { вправи }\end{array}$ & $\begin{array}{l}\text { некомунікативні й умовно-комуніка- } \\
\text { тивні вправи на формування лексичних } \\
\text { навичок; } \\
\text { - некомунікативні й умовно-комуніка- } \\
\text { тивні вправи на формування граматичних } \\
\text { навичок. }\end{array}$ \\
\hline $\begin{array}{l}\text { Аналітичний } \\
\text { етап }\end{array}$ & $\begin{array}{l}\text { Група 2: } \\
\text { рецептивно- } \\
\text { аналітичні } \\
\text { вправи }\end{array}$ & $\begin{array}{l}\text { впмпави на визначення структурно- } \\
\text { ААП; } \\
\text { - вправи на визначення логіки викладу } \\
\text { композиції визначених жанрів ААП; } \\
- \text { вправи на визначення мовних засобів } \\
\text { для вираження тези, аргументів, виснов- } \\
\text { ків, а також засобів зв'язку компози- } \\
\text { ційних частин. }\end{array}$ \\
\hline
\end{tabular}


Закінчення таблиці 1

\begin{tabular}{|c|c|c|}
\hline $\begin{array}{l}\text { Тренувальний } \\
\text { етап }\end{array}$ & $\begin{array}{l}\text { Група 3: } \\
\text { репродуктивно- } \\
\text { трансформаційні } \\
\text { завдання }\end{array}$ & $\begin{array}{l}\text { - завдання на формулювання правового } \\
\text { питання (тези); } \\
\text { - завдання на формулювання аргументів, } \\
\text { що підтримують власну позицію; } \\
\text { - завдання на формування аргумента- } \\
\text { тивних умінь. }\end{array}$ \\
\hline $\begin{array}{l}\text { Текстово- } \\
\text { продукувальний } \\
\text { етап }\end{array}$ & $\begin{array}{l}\text { Група 4: } \\
\text { виконавчі } \\
\text { завдання на } \\
\text { продукування } \\
\text { визначених } \\
\text { жанрів ААП }\end{array}$ & $\begin{array}{l}\text { - завдання на удосконалення аргумента- } \\
\text { тивних умінь; } \\
\text { - завдання на продукування та перевірку } \\
\text { текстово-продукувальних умінь ААП. }\end{array}$ \\
\hline
\end{tabular}

Для глибшого розуміння практичної реалізації представленої підсистеми справ і завдань для е-навчання ААП студентів-правників вважаємо за необхідне у межах цього дослідження проілюструвати кожну групу вправ і завдань відповідними зразками.

Група 1 (Вправа 1): Мета: формувати лексичних навичок. Очікуваний результат: студенти знатимуть лексичні одиниці, характерні для юридичного писемного мовлення у сфері захисту персональних даних. Інструменти системи Moodle, за допомогою яких реалізується завдання: Тест. Тип вправи: рецептивна, некомунікативна, письмова, одномовне, тренувальна. Спосіб виконання: індивідуально. Контроль: 3 боку системи; завдання зараховується у разі правильного виконання $60 \%$; кількість спроб необмежена; форма оцінювання - краща оцінка. Інструкція: Read Article 8 of the EU Directive on Personal Data Protection. Find the words in the text which mean the following:

1) a law, rule, or system that protects people or things from being harmed or lost;

2) not able to do something;

3) clear and exact;

4) acceptable or allowed by law;

5) the person (including a company) who determines the purposes for which, and the manner for which, any personal data are processed;

6) a law or rule that says people must not do something;

7) a living individual about whom a holds personal;

8) an occasion when a rule or law is allowed to be ignored;

9) the fact of making sure that nothing is known about sth;

10) an organization that represents people who do a particular job. 
Article 8. The processing of special categories of data

1. Member States shall prohibit the processing of personal data revealing racial or ethnic origin, political opinions, religious or philosophical beliefs, tradeunion membership, and the processing of data concerning health or sex life.

2. Paragraph 1 shall not apply where:

(a) the data subject has given his explicit consent to the processing of those data, except where the laws of the Member State provide that the prohibition referred to in paragraph 1 may not be lifted by the data subject's giving his consent; or

(b) processing is necessary for the purposes of carrying out the obligations and specific rights of the controller in the field of employment law in so far as it is authorized by national law providing for adequate safeguards; or

(c) processing is necessary to protect the vital interests of the data subject or of another person where the data subject is physically or legally incapable of giving his consent; or

(d) processing is carried out in the course of its legitimate activities with appropriate guarantees by a foundation, association or any other nonprofit-seeking body with a political, philosophical, religious or trade-union aim and on condition that the processing relates solely to the members of the body or to persons who have regular contact with it in connection with its purposes and that the data are not disclosed to a third party without the consent of the data subjects; or

(e) the processing relates to data which are manifestly made public by the data subject or is necessary for the establishment, exercise or defence of legal claims.

3. Paragraph 1 shall not apply where processing of the data is required for the purposes of preventive medicine, medical diagnosis, the provision of care or treatment or the management of health-care services, and where those data are processed by a health professional subject under national law or rules established by national competent bodies to the obligation of professional secrecy or by another person also subject to an equivalent obligation of secrecy.

4. Subject to the provision of suitable safeguards, Member States may, for reasons of substantial public interest, lay down exemptions in addition to those laid down in paragraph 2 either by national law or by decision of the supervisory authority.

5. Processing of data relating to offences, criminal convictions or security measures may be carried out only under the control of official authority, or if suitable specific safeguards are provided under national law, subject to derogations which may be granted by the Member State under national provisions providing suitable specific safeguards. However, 
a complete register of criminal convictions may be kept only under the control of official authority.

Member States may provide that data relating to administrative sanctions or judgements in civil cases shall also be processed under the control of official authority.

6. Derogations from paragraph 1 provided for in paragraphs 4 and 5 shall be notified to the Commission.

7. Member States shall determine the conditions under which a national identification number or any other identifier of general application may be processed.

Група 1 (Вправа 2): Mema: формувати граматичні навички. Очікуваний результат: студенти зможуть вживати модальні дієслова, описуючи права й обов'язки сторін конфлікту. Інструменти системи Moodle, за допомогою яких реалізується завдання: Тест. Тип вправи: рецептивно-репродуктивна, некомунікативна, письмова, одномовна, тренувальна. Спосіб виконання: індивідуально. Контроль: із боку системи; завдання зараховується у разі правильного виконання $60 \%$; кількість спроб необмежена; форма оцінювання - краща оцінка. Інструкиія: Choose the correct option to complete the gaps.

1. In accordance with this Directive, Member States ... protect the fundamental rights and freedoms of natural persons.
A shall
B may
C must

2. In the circumstances referred to in paragraph 1 (c), the controller ... designate a representative established in the territory of that Member State.
A shall
B may
C must

3. Member State shall provide that personal data ... be processed only if (a) the data subject has unambiguously given his consent.
A shall
B may
C must

4. Member State ... adopt legislative measures to restrict the scope of the obligations and rights provided for in Articles 6 (1), 10, 11 (1), 12 and 21.
A shall
B may
C must

5. Member State shall provide that the controller or his representative, if any, ... notify the supervisory authority referred to in Article 28 before carrying out any wholly or partly automatic processing operation or set of such operations intended to serve a single purpose or several related purposes.
A shall
B may
C must

6. Member State ... specify the information to be given in the notification.
A shall
B may
C must

Група 2 (Вправа 3): Мeта: ознайомити зі структурнокомпозиційними частинами листа-поради як жанру ААП. Очікуваний 
результат: студенти зможуть визначити композиційні частини листапоради. Інструменти системи Mооdle, за допомогою яких реалізується вправа: Тест. Тип вправи: рецептивно-аналітична, некомунікативна, письмова, одномовна, тренувальна. Спосіб виконання: індивідуально. Контроль: із боку системи; завдання зараховується у разі правильного виконання 60\%; кількість спроб необмежена; форма оцінювання краща оцінка. Інструкиія: Read the text which follows a standard pattern for a letter of advice from a lawyer to a client. Match each paragraph (1-6) with its correct label (a-f):

Dear Mr Johnson,

(1) Thank you for coming to see me on 17 March when we discussed the situation regarding Mr. Brown's refusal to pay $\$ 1,000$ bonus under the agreement concluded between Mr. Brown and you. I am writing to summarise our discussion and confirm your instructions.

(2) You told me that Mr. Brown contacted your marketing company in Manchester to advertise the event "Save the Planet Day" that he decided to hold in St. James Park near his home in London on 15 February. Mr. Brown had a phone conversation with the manager of your company and the manager told him that the cost of promoting the event is $\$ 5,000$. Mr. Brown agreed and paid a deposit of $\$ 500$ by his credit card. After that, you told us that Mr. Brown phoned your manager a week before the event and he promised to pay o bonus of $\$ 1,000$ if you can persuade the ethical Food Company to come to the event. After persuading the Ethical Food Company to come to the event, Mr. Brown refused to pay the $\$ 1,000$ and said the original payment covers everything.

(3) The legal issue here is whether or not the manager of your company has concluded an extra-agreement with Mr. Brown and whether or not Mr. Brown is obliged to pay $\$ 1,000$ of bonus.

(4) In your situation the legal relationships are regulated by the legal provisions of Williams v. Roffey Ltd case (1991). According to the case of Williams v. Roffey Ltd case, since there was no duress or threat for the extra payment and the offer of extra money from Mr. Brown was made willingly and voluntarily, the extra benefit one of the parties receives (in our case the attendance of the Ethical Food company), should be paid for with extra consideration from Mr. Brown. Based on the abovementioned, we strongly believe that Mr. Browm is obliged to pay an extra $\$ 1,000$ to your company.

(5) I will write a letter to Mr. Brown on your behalf outlining the above and notifying him that he is obliged to pay the extra $\$ 1,000$ as a bonus. I will require confirmation from Mr. Brown to accept our interpretation and the relevant case law.

(6) I will be in touch again shortly. Please do not hesitate to contact me if you have any questions. 
Kind regards,

Linda Jefferson.
a) Opening paragraph
b) Closing paragraph
c) The lawyer's proposed actions
d) The lawyer's advice
e) Summary of the facts
f) The legal issue(s)

Група 3 (Завдання 3): Мета: формування аргументативних умінь шляхом інтегрування умінь формулювання тези, аргументів і висновку. Очікуваний результат: студенти зможуть сформулювати тезу, навести вагомі аргументи та сформулювати висновки, що базуватимуться на чинному законодавстві. Інструменти системи Moodle, за допомогою яких реалізується вправа: Форум. Тип завдання: продуктивне, комунікативне, письмове, одномовне, тренувальне. Спосіб виконання: індивідуально. Контроль: із боку системи перевіряється факт виконання завдання студентами; з боку викладача перевіряється зміст повідомлення та надається рефлексія у формі коментаря. Інструкиія: Comment on the following situations stating a legal issue, providing arguments and making a relevant conclusion.

1) At the job interview Mrs. White was required to fulfill the questionnaire where she needed, inter alia, to tell about her trade-union membership. After her refusal, she wasn't offered a position.

2) At a popular talk show devoted to celebrities' lifestyle, they talked about details of a famous actor's last illness and treatment. The information was taken from social networks and actors' friends who had come to the studio.

3) When being at the doctor, Mrs. Jones was asked to provide a staff member with details of her health and sex life. After two weeks, Mrs. Jones' neighbor told her that she knew everything about her from her cousin who worked for Mrs. Jones' doctor.

4) The journalist revealed on his Facebook page the information about a politician's personal life, inter alia, his children's place of study, his wife's place of work and details of their last holiday. All the information was taken by the journalist from social networks such as Facebook, Twitter and Instagram.

Група 4 (Завдання 2): Mema: удосконалювати текстовопродукувальні уміння ААП без опори на попереднє обговорення ситуації спілкування, в межах якої вона реалізується. Очікуваний результат: студенти зможуть індивідуально та самостійно написати лист-пораду як жанр ААП. Інструменти системи Moodle, за допомогою яких реалізується завдання: Завдання; Файл. Тип вправи: 
комунікативна, письмова, одномовна, контрольна. Спосіб виконання: індивідуально. Контроль: із боку викладача. Час виконання: 60 хвилин. Кількість спроб: 1. Інструкиія: You are Mary Brown's lawyer. Write a letter of advice in approximately 200-250 words.

Mary Brown was a patient of a local hospital. Last week she watched a TV show devoted to Health Care where the journalists described her case mentioning her first name and demonstrating her photo. She was very much shocked as she didn't provide any consent on processing her personal data. Now she wants to bring a claim against a TV channel for violation the UK Regulation on Personal Data Protection.

\section{ВИСНОВКИ}

Отже, е-навчання ААП майбутніх правознавців ми пропонуємо здійснювати у чотири етапи (підготовчий, аналітичний, тренувальний i текстово-продукувальний) за допомогою визначеної підсистеми вправ і завдань. Успішність реалізації кожного етапу залежить від досягнення поставлених цілей. Так, підготовчий етап націлений на формування мовленнєвих навичок у продукуванні ААП в межах відповідного жанру та на подолання мовних і предметних труднощів; на аналітичному етапі ставимо за мету проаналізувати готові тексти для визначення композиційних і жанрово-стилістичних особливостей різних жанрів юридичного дискурсу: лист-пораду, лист-попередження, лист-відповідь на попередження, меморандум, позовну заяву; тренувальний етап спрямований на досягнення таких цілей, як формулювання тези, аргументів і висновку, а також подолання логічних труднощів; цілями текстово-продукувального етапу визначаємо удосконалення аргументаційних умінь і формування текстово-продукувальних умінь.

\section{АНОТАЦІЯ}

У роботі досліджені деякі методичні аспекти формування умінь англійського аргументативного письма майбутніх правознавців в умовах е-навчання. На основі аналізу теоретичних праць вітчизняних $\mathrm{i}$ зарубіжних вчених авторка представляє чотири етапи е-навчання англійського аргументативного письма. Кожен етап спрямований на формування мовних навичок і мовленнєвих умінь, необхідних для успішного продукування юридичного аргументативного письма англійською мовою. 3 метою ефективної реалізації етапів е-навчання англійського аргументативного письма майбутніх юристів авторка також розробляє підсистему вправ і завдань. Сформульовано низку умов, необхідних для ефективного формування аргументативних умінь. Визначено чотири групи вправ різних типів і видів, проілюстровані конкретними прикладами. Для кожної вправи чи завдання визначено 
низку параметрів, а саме: мету, очікуваний результат, інструменти системи Moodle, за допомогою яких реалізується вправа / завдання, тип вправи, спосіб виконання, контроль, час виконання, кількість спроб, інструкцію.

\section{ЛІТЕРАТУРА}

1. Антонова И.Б. Методическая эффективность использования письма как средства обучения аргументированию в неязыковом вузе: английский язык : дис. ... канд. пед. наук : 13.00.02 / Моск. лингвистический ун-т. Москва, 1994. 254 с.

2. Баранова Е.А. Методика обучения аргументированному письменному высказыванию: на материале французского языка, языковой факультет : автореф. дис. ... канд. пед. Наук : 13.00 .02 / Моск. гос. гуманитар. ун-т им. М.А. Шолохова. Орел, 2013. 23 с.

3. Батурина Ю.В. Формирование аргументативных стратегий у магистрантов-психологов с использованием сетевых компьютерных технологий: на материале английского языка : дис. ... канд. пед. наук : 13.00.02 / Санкт-Петербургский гос. ун-т. Санкт-Петербург, 2015. 275 с.

4. Бим И.Л. Методика обучения иностранным языкам как наука и проблема школьных учебников: опыт системно-структурного описания. Москва : Русский язык, 1977. 288 с.

5. Білоус С.В. Навчання майбутніх філологів англійського усного монологічного персуазивного мовлення : дис. ... канд. пед. наук : 13.00.02 / КНУ імені Т. Шевченка. Київ, 2017. 228 с.

6. Гаврилова А.Н. Формирование письменно речевой аргументативной компетенции у студентов гуманитарных специальностей (английский язык) : дис. ... канд. пед. наук : 13.00.02 / Санкт-Петербургский гос. ун-т. Санкт-Петербург, 2011. 277 с.

7. Дацюк В.В. Обучение студентов восточного факультета аргументативным стратегиям англоязычного делового дискурса : дисс. ... канд. пед. наук : 13.00 .02 / Санкт-Петербургский гос. ун-т. Санкт-Петербург, 2016. 233 с.

8. Заярна I.C. Етапи навчання англійського аргументативного письма майбутніх правознавців. Актуальні питання розвитку юридичної науки та практики : матеріали Міжнародної науковопрактичної конференції (15 листопада 2019 р.) / за заг. ред. І.С. Гриценка, І.С. Сахарук. Київ, 2019. С. 578-580.

9. Методика викладання іноземних мов у середніх навчальних закладах : підручник / кол. авт. під керівн. С.Ю. Ніколаєвої. Київ : Ленвіт, 2002. 328 с.

10. Мусульбес С.Н. Обучение аргументирующему дискурсу в сфере письменного общения: (языковой вуз, продвинутый этап, 
английский язык) : дис. ... канд. пед. наук : 13.00.02 / Моск. гос. лингв. ун-т. Москва, 2005. 202 с.

11. Патієвич О.В. Методика навчання стилістичної унормованості наукового писемного англійського мовлення майбутніх фізиків в умовах магістратури : дис. ... канд. пед. наук : 13.00.02 / М-во освіти і науки України, Київ. нац. ун-т імені Тараса Шевченка. Київ, 2015. $276 \mathrm{c}$.

12. Плахотник В.М. Чи можуть вправи бути комунікативними. Іноземні мови. 2009. № 3. С. 3-5.

13. Скляренко Н.К. Сучасні вимоги до вправ для формування іншомовних мовленнєвих навичок та вмінь. Іноземні мови. 1999. № 3. C. $3-7$.

14. Цепкало О.В. Методика навчання комунікативних стратегій професійно спрямованого англомовного писемного спілкування майбутніх фахівців з машинобудування : дис. ... канд. пед. наук: 13.00.02 / НТУ КПІ імені І. Сікорського. Київ, 2017. 244 с.

15. Шатилов С.Ф. Методика обучения немецкому языку в средней школе. Москва : Просвещение, 1986. 221 с.

16. Шевніна Л.С. Формування жанрової компетенції в англійському діловому писемному мовленні майбутніх менеджерів туризму : автореф. дис. ... канд. пед. наук : 13.00.02 / ПНПУ ім. К.Д. Ушинського. Одеса, 2012. 23 с.

Information about the author: Zaiarna I. S., $\mathrm{PhD}$ in Pedagogy, Assistant Professor at the Foreign Languages Department of the Faculty of Law Taras Shevchenko National University of Kyiv 60, Volodymyrska str., Kyiv, Ukraine 